\title{
Canine Distemper Virus and it's interaction within the Galapagos Islands ecosystem
}

\author{
Ben Howitt*, Jessie Olson and Patricio Alejandro Vega Mariño \\ Ashley Farmhouse, Ashley, Box, Corsham, Wiltshire, UK SN13 8AJ \\ *Corresponding author: Ben Howitt, Ashley Farmhouse, Ashley, Box, Corsham, Wiltshire, UK SN13 8AJ
}

$\overline{\text { ARTICLE INFO }}$ ABSTRACT

Received: 㓞 January 30, 2020

Published: 慧 February 10, 2020

Citation: Ben Howitt, Jessie Olson, Patricio Alejandro Vega Mariño. Canine Distemper Virus and it's interaction within the Galapagos Islands ecosystem. Biomed J Sci \& Tech Res 25(3)-2020. BJSTR. MS.ID.004204.
Keywords: Endemic Species; Volcanic Archipelago; Galapagos; Antibody; Toxoplasma Gondii

Abbreviations: CDV: Canine Distemper Virus; CPV: Canine Parvo Virus; PDV: Phocine Distemper Virus; RT-PCR: Reverse Transcriptase Polymerase Chain Reaction

\section{Introduction}

The Galapagos is well known to boast one of the highest concentrations of endemic species, some with incredible adaptations, that can be found nowhere else within the animal kingdom. The islands do not only have one ecosystem, but hundreds scattered across the volcanic archipelago, some isolated to just one volcano. Because these ecosystems can be so small, they house such small populations, and with this fragility comes a risk that any upset in the ecosystems balance can bring some species close to the edge of extinction. Yet despite being an isolated community, dogs and cats have been a very common sight within and around the edges of the urbanised areas for a few decades. Even with strict laws where breeding and importation of domesticated animals from the mainland is illegal, the population has steadily increased since a study in 2014 suggested there was a population of 2,503 domestic canines on Santa Cruz island alone [1]. With a population increase comes associated problems, and this study demonstrated that the domestic canines were not all free of the diseases found on the South American continent, with 36\% of those tested on Santa Cruz found to have positive antibody titres to Canine Distemper Virus (CDV).

Another study in 2008 on the island of Isabela demonstrated similar results, reporting that $63 \%$ of cats had antibodies to Toxoplasma gondii, $100 \%$ of dogs had antibodies to Canine Parvo
Virus (CPV-2), and $22 \%$ of dogs had antibodies to CDV [2]. Invasive species may be prone to upsetting ecosystems through predation and competition for resources, but the acknowledgement of the presence of infectious diseases in the Galapagos has added a whole other risk to the wildlife. Previous to these studies, CDV had been officially recorded in the canine population of the Galapagos on one other occasion; in 2001 when an outbreak of CDV killed more than 600 dogs on Santa Cruz and Isabela Islands [1,2].

CDV is well known to be a highly prevalent infectious virus with a worldwide distribution [3], and what makes it eradication considerably challenging and concerning is that it exhibits the ability to adapt to a broad number and range of hosts. Seals and Sealions have been seen to be particularly susceptible to both CDV and Phocine Distemper Virus (PDV). As seen in 1988, two separate outbreaks in Harbor and Siberian seals, with no epidemiological connection to each other, brought it to the world's attention. The first was seen in Harbor seals in the North and Baltic Sea area of Northern Europe, and the second in Siberian seals in the Siberian Baikal region, showing significant mortality rates [4]. Again in 2000 , this time in the Caspian Sea, there were high mortality rates within the Caspian seal populations, in which more than 10,000 seals were to have estimated to have died [5]. Using Reverse Transcriptase Polymerase Chain Reaction (RT-PCR), CDV was 
isolated and determined to be the primary cause. Though the route of transmission was unconfirmed, domestic dogs and wolves were the suspected vectors of the disease [6].

Across the Galapagos Island, domestic dogs freely roam some of the beaches, leaving beach-dwelling sealions at potential risk of CDV transmission. This potential for CDV transmission to the Galapagos sealion (Zalophus wollebaeki) was confirmed in 20112012 when CDV was detected in the tissues of six sea lions [7] Further testing of 109 juvenile sealions in 2014 showed an absence of CDV antibodies and the 2011 cases were thought to have been an isolated incident. In more recent years and in the months of June through September 2019, 148 Domestic canines from Santa Cruz Island presented to the governmental facility as well as a local veterinary clinic with indicators of CDV. Through clinical observations and RT-PCR testing data, clinical signs were recorded for suspected cases. With the results of the RT-PCR, this outbreak revealed that $74 \%$ were seropositive for $\mathrm{CDV}$, and a publication will be released on this outbreak this coming year. This outbreak was of particular concern as vaccines, despite only being permitted on the islands in 2017, had already been around for a few years [1].

It is undetermined how CDV infections from domestic dogs to the sealions will impact the populations on the Galapagos [1,7]. While the virus is extremely infectious, the severity of CDV in dogs and wildlife populations depends on several epidemiological factors such as the virulence of the virus strain, population density, herd immunity, host age, immune status, and environmental stress [8]. Nonetheless, CDV, Parvovirus, and parasites are a persistent threat to the biodiversity of the Galapagos, and domestic canines unfortunately remain both a reservoir and a source.

\section{References}

1. Diaz NM, Mendez GS, Grijalva CJ, Walden HS, Cruz M, et al. (2016) Dog Overpopulation and Burden of Exposure to Canine Distemper Virus and Other Pathogens on Santa Cruz Island, Galapagos. Preventative Veterinary Medicine 123: 128-137.

2. Levy J K, PC Crawford, MR Lappin, EJ Dubovi, MG Levy, et al. (2008) Infectious Diseases of Dogs and Cats on Isabela Island, Galapagos. Journal of Veterinary Internal Medicine 22(1): 60-65.

3. Martinez Gutierrez M, Ruiz Saenz J (2016) Diversity of Susceptible Hosts in Canine Distemper Virus Infection; a systematic review and data synthesis. BMC Veterinary Research 12(1): 78.

4. Beineke, Baumgärtner W, Wohlsein P A (2015) Cross Species Transmission of Canine Distemper Virus an Update. One Health 1: 49-59.

5. S Kennedy, T Kuiken, P D Jepson, R Deaville, M Forsyth, et al. (2000) Mass Die-Off of Caspian Seals caused by Canine Dsitmeper Virus. Emerging Infectious Diseases 6(6): 637-639.

6. Wilson S, Eybatov TM, Amano M, Jepson PD, Goodman SJ (2014) The Role of Canine Distemper Virus and Persistent Organice Pollutant in Mortality Pattern of Caspian Seals (Pusa Caspica). PLoS ONE 9(7).

7. Denkinger J, Guevara N, Ayala S, Murillo JC, Hirschfeld M, et al. (2017) Pup Mortality and Evidence for Pathogen Exposure in Galapagos Sealion (Zalophus wollabaeki) on San Cristobal Island, Galapagos, Ecuador Journal of Wildlife Diseases 53(3): 491-498.

8. Maclachlan J N, Dubovi E J (2016) Fenners Veterinary Virology. Elsevier.

\section{ISSN: 2574-1241}

DOI: 10.26717/BJSTR.2020.25.004204

Ben Howitt. Biomed J Sci \& Tech Res

This work is licensed under Creative Commons Attribution 4.0 License

Submission Link: https://biomedres.us/submit-manuscript.php

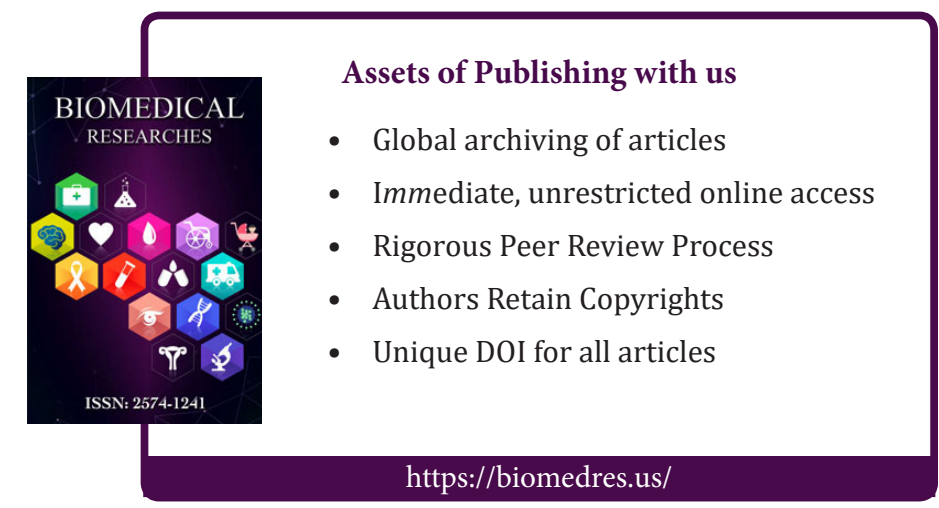

